\title{
Evaluation of nine serological rapid tests for the detection of SARS-CoV-2
}

\author{
Marcela Mercado ${ }^{1}$, Jeadran Malagón-Rojas², Gabriela Delgado³, Vivian Vanesa Rubio', Lida Muñoz

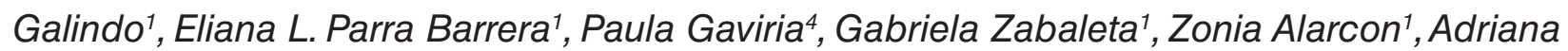 \\ Arévalo ${ }^{1}$, Helly Casallas Cifuentes ${ }^{1}$, Kelly Estrada ${ }^{5}$, Gloria Puerto ${ }^{1}$, María T. Herrera Sepúlveda ${ }^{1}$, Helena \\ Rodríguez ${ }^{1}$, Marisol Galindo ${ }^{1}$, and Martha Lucía Ospina Ramírez ${ }^{1}$
}

Suggested citation Mercado M, Malagón-Rojas J, Delgado G, Rubio VV, Muñoz Galindo L, Parra Barrera EL et al. Evaluation of nine serological rapid tests for the detection of SARS-CoV-2. Rev Panam Salud Publica. 2020;44:e149 https://doi.org/10.26633/RPSP.2020.149

ABSTRACT

Objective. To evaluate the operative capacity of nine serological rapid tests to detect the $\operatorname{lgM} / \operatorname{lgG}$ antibodies response in serum from patients with SARS-CoV-2 in different clinical stages.

Methods. A cross-sectional study of serological rapid tests was designed to compare the performance of the evaluated immunochromatographic tests for the diagnosis of SARS-CoV-2. A total of 293 samples was used, including negatives, asymptomatic, and symptomatic serum samples.

Results. The sensitivity of the evaluated tests was low and moderate in the groups of asymptomatic serum samples and the group of serums coming from patients with less than 11 days since the onset of the symptoms. The specificity for the anti-SARS-CoV-2 antibodies tests ranged between $86.5 \%-99 \%$ for IgM and $86.5 \%-99.5 \%$ for IgG. The sensitivity and the likelihood ratio were different according to the study groups. The usefulness of these tests is restricted to symptomatic patients and their sensitivity is greater than $85 \%$ after 11 days from the appearance of symptoms.

Conclusions. Serological tests are not an adequate strategy for the identification of asymptomatic and pre-symptomatic patients. Serological rapid tests for the detection of specific anti-SARS-CoV-2 antibodies can be used as a diagnostic aid, but diagnosis must be confirmed by RT-PCR. Rapid tests should be reserved for patients with symptoms lasting more than 11 days.

Keywords Betacoronavirus; coronavirus infections; serologic tests; diagnostics; Colombia.

Since the SARS-CoV-2 atypical pneumonia was reported in December 2019 in China (1), the world has focused on research toward a better understanding of the virus and the infection in humans, including the development of diagnostic tests for early detection, treatment, and reducing mortality associated with the virus (2). In the current context of the pandemic, one of the main challenges is the early detection of SARS-CoV-2 cases at the community level with some risk such as hospitals, nursing homes, penitentiary centers, and passenger transport in airports and terminals $(3,4)$.

Serological rapid tests are particularly important for early detection; these tests are easy to operate and allow a rapid screening of SARS-CoV-2 antibodies within 10-15 minutes (5), helping to have a better understanding of the humoral

\footnotetext{
Instituto Nacional de Salud, Bogotá, Colombia.

2 Facultad de Medicina de la Universidad El Bosque, Bogotá, Colombia. $\square$ Jeadran Malagón-Rojas, jmalagon@ins.gov.co

3 Universidad Nacional de Colombia, Bogotá, Colombia.
}

\footnotetext{
Instituto Distrital de Ciencia, Biotecnología e Innovación en Salud, Bogotá, Colombia.

5 Instituto de Evaluación Tecnológica en Salud, Bogotá, Colombia.
} 
response of infected patients (6). Because of their low cost and easy processing, in some scenarios these types of tests have been used as a screening tool for the general population. However, some manufacturers have stated that the serological rapid test requires the concomitant use of RT-PCR due to the falsenegative rate that can result (7).

Serological rapid tests generally use a conjugate made up of a reagent (usually colloidal gold) that is activated in the presence of viral antigens or antibodies against human IgM/IgG. Activation is visible on the nitrocellulose plate in a colored band. Currently, a large number of serological tests are available, which present different operational capabilities for the detection of SARS-CoV-2 antibodies. However, this detection capacity has been questioned by the World Health Organization (8). The aim of this study was to evaluate the operative capacity of serological rapid tests to detect the IgM/IgG antibodies response in serum of patients with SARS-CoV-2 in different clinical stages.

\section{METHODS}

A cross-sectional study of the diagnostic tests was designed to compare the performance of nine immunochromatographic tests for the diagnosis of SARS-CoV-2. A minimum sample size of 293 was estimated according to the sensitivity parameter (9), and a margin error of $10 \%$, with a confidence level of $95 \%$. The available serum was distributed in four groups: i) patients with SARS-CoV-2 and positive RT-PCR who developed mild, moderate, and severe COVID-19; ii) asymptomatic patients with positive RT-PCR; iii) patients with negative RT-PCR tests; and iv) "historic negatives", i.e., serum collected before the pandemic in 2017-2018 and stored in the Instituto Nacional de Salud biobank, which was used as a control for the tests since these should not have anti-SARS-CoV-2 antibodies (10).

\section{Exclusion criteria}

Serum samples from patients were excluded if they had a history of autoimmune disease such as rheumatoid arthritis, lupus erythematosus, and Sjögren syndrome, among others. Likewise, serum was excluded in those who received transfusions in the last month before taking the blood sample, pregnant women, and minors.

\section{Reference test}

As the gold standard technique real-time PCR test with reverse transcriptase (RT-PCR, Diagnostic detection of 2019nCoV by real-time RT-PCR, Charité Virology, Berlin, Germany) was used. RT-PCR consists of a polymerase chain reaction that has previously had a reverse transcription (RT) phase. Using RT, cDNA was obtained from an RNA strand. Consequently, the RT-PCR technique performs the detection and amplification of a sequence from a strand of RNA. This presents a technical limit of detection $(\mathrm{LOD})=5.2$ RNA copies/reaction, at a $95 \%$ hit rate; $95 \% \mathrm{CI}$ : 3.7-9.6 copies of RNA/reaction, according to the protocol (11).

\section{Type of tests used}

The immunochromatographic assay was used for the qualitative detection of SARS-CoV-2 specific IgG/IgM antibodies.
According to the manufacturing information, these tests can detect anti-SARS-CoV-2 antibodies in whole venous blood, whole blood by capillary puncture, serum, and plasma samples. According to the manufacturer's instructions, the test is positive when a red band is generated, one for $\operatorname{Ig} \mathrm{M}$, another for IgG, and one for control (Table 1).

\section{Clinical data}

The sociodemographic and clinical data were obtained from the epidemiological reports from the National Epidemiological System (SIVIGILA). It included age, sex, place of residence, type of infection (asymptomatic and symptomatic), date of onset of symptoms, severity of infection, etc.

\section{Collection of serum samples}

With the results of molecular tests taken from samples of nasopharyngeal swabs in different groups of individuals (symptomatic, asymptomatic, and negative), a cohort of positive patients was followed up on the $7^{\text {th }}, 14^{\text {th }}$, and $21^{\text {st }}$ day after the first nasopharyngeal swab. This was carried out to obtain blood samples to determine the presence of antibodies over 14 days post-infection.

\section{Test procedure}

Before measuring and verifying the humidity and temperature described on the inserts of each test, $10 \mu \mathrm{L}$ or $5 \mu \mathrm{L}$ of serum was served in the well. Subsequently, 2 or 3 drops of running buffer were added. The presence of movement in the nitrocellulose column was observed after the incubation time of 10 to 15 minutes, and the reading was then performed according to the manufacturer's instructions.

\section{Test evaluation}

The cassettes results were interpreted and reported by two independent evaluators. The results of the readings were transcribed by each of the evaluators independently. Subsequently, a third researcher reviewed the database to check for transcription errors or inconsistencies.

\section{Statistical analysis}

Point and interval estimates of $95 \%$ of the operational characteristics of the tests concerning sensitivity, specificity, positive likelihood ratio, positive and negative predictive value (PPV and NPV respectively) were established $(12,13)$. Also, the group of historical negatives was used to estimate the divergent criteria validity.

A pooled analysis was performed for sensitivity and specificity. Also, $\mathrm{I}^{2}$ was estimated. An $\mathrm{I}^{2}>50 \%$ was considered as moderate heterogeneity; an $\mathrm{I}^{2} \geq 75 \%$ was considered high $(14,15)$.

According to the observed heterogeneity $\left(\mathrm{I}^{2}\right)$, subgroups were formed excluding tests involved in the high inconsistency. Forest plots with test-specific and overall point estimates and $95 \%$ confidence intervals (CI) were carried out. The analysis was performed with SPSS ${ }^{\circledR}$ V. 16.1 statistical program, licensed by the INS. Forest plots were made in Meta-DiSc ${ }^{\circledR}$ V. 1.4, free license (16). 


\section{Ethical considerations}

The study was approved by the Ethics Committee of the INS in June of 2020.

\section{RESULTS}

A total of 293 serum samples were included in the study, including 100 historical negatives. In the 2020 group, most of the samples corresponded to male patients $(65.8 \%, \mathrm{n}=127)$, with an average age of 38 years (SD 12). $48.2 \%(n=93)$ out of the samples corresponded to positive serums (table 2).

Nine immunochromatographic assays were evaluated. Table 3 shows the performance results of each test in three groups of serum: asymptomatic patients, patients with $\leq 11$ days of symptoms, and patients with $\geq 11$ days of evolution.

In general, the tests showed adequate specificity to rule out the presence of IgM and IgG antibodies when anti-SARS-CoV-2 immunoglobulins were not present. The specificity ranged between $86.5 \%$ and $99 \%$ for $\operatorname{IgM}$, and $86.5 \%$ and $99.5 \%$ for $\operatorname{IgG}$. However, the sensitivity and the likelihood ratio varied according to the study groups.

Regarding the measurement of the validity of the divergent criteria (VDC), when evaluated with the historical negative serums, VDC presented values greater than $95 \%$ for $\operatorname{IgM}$ and $96 \%$ for IgG in 8 of the 9 tests evaluated. In the Leccurate ${ }^{\circledR}$ test this value was $84 \%$ (95\% CI 75.4 - 91.4) for IgM and $86 \%$ (95\% CI 77.7 - 91.6) for IgG, which should be analyzed in light of the possibility of a large number of false positives that may be related to cross-reaction to other type of antibodies non-specific to SARSCoV-2 (table 3).

\section{Asymptomatic patients}

In the nine tests evaluated, the sensitivity of the $\operatorname{IgM}$ and IgG in samples from asymptomatic patients was less than $50 \%$. In contrast, specificity was greater than $85 \%$. The likelihood ratio had values between 3.50 and 33 .

\section{TABLE 1. Characteristics of the evaluated tests}

\begin{tabular}{|c|c|c|c|c|c|c|c|c|c|}
\hline Test & $\begin{array}{l}\text { Type of } \\
\text { cassette }\end{array}$ & $\begin{array}{c}\text { Place of } \\
\text { manufacturing }\end{array}$ & Type of test & $\begin{array}{l}\text { Reading time } \\
\text { (min) }\end{array}$ & $n$ & $\begin{array}{l}\text { Sensitivity } \\
\lg M(\%)\end{array}$ & $\begin{array}{l}\text { Specificity } \\
\lg M(\%)\end{array}$ & $\begin{array}{l}\text { Sensitivity } \\
\lg G(\%)\end{array}$ & $\begin{array}{l}\text { Specificity } \\
\lg \mathrm{G}(\%)\end{array}$ \\
\hline Biosensor $^{\circledR}$ & Duo & Republic of Korea & Colloidal gold & $10-15$ & 40 & 91.70 & 100 & 79.20 & 100 \\
\hline AMS International ${ }^{\circledR}$ & One & United Kingdom & Colloidal gold & $10-15$ & 360 & 95.70 & 97.30 & 91.80 & 96.40 \\
\hline Leccurate $^{\circledR}$ & One & China & Colloidal gold & $10-20$ & NR & 90 & 100 & NR & NR \\
\hline $\begin{array}{l}\text { HIGHTOP One Step } \\
\text { rapid test }^{\circledR}\end{array}$ & One & China & Colloidal gold & $10-20$ & 1300 & 82 & 96 & 93 & 97.50 \\
\hline Cromatest COVID-19 ${ }^{\circledR}$ & One & China & Colloidal gold & $10-15$ & 551 & 78.03 & 99.39 & 96.86 & 100 \\
\hline AMP Rapid Test ${ }^{\circledR}$ & One & Austria & Colloidal gold & 10 & NR & 95.70 & 97.30 & 91.80 & 96.40 \\
\hline Egens $^{\circledR}$ & One & China & Colloidal gold & 10 & NR & 96.88 & 100 & 96.88 & 100 \\
\hline Cellex ${ }^{\circledR}$ & One & United States & Colloidal gold & $15-20$ & 378 & 93.75 & 96.40 & 93.75 & 96.40 \\
\hline Onesite Rapidtest ${ }^{\circledR}$ & One & United States & Colloidal gold & $10-15$ & 551 & 78.03 & 99.39 & 96.86 & 100 \\
\hline
\end{tabular}

NR, not reported

TABLE 2. Sociodemographic characteristics of the population

\begin{tabular}{|c|c|c|c|c|c|c|}
\hline \multirow[t]{2}{*}{ Group } & \multicolumn{2}{|c|}{$\begin{array}{l}\text { Sex } \\
\%(n)\end{array}$} & \multirow[t]{2}{*}{ Mean age (years) } & \multirow[t]{2}{*}{$\mathrm{SD}$} & \multirow[t]{2}{*}{$\begin{array}{l}\text { Symptoms duration } \\
\text { (days) }\end{array}$} & \multirow[t]{2}{*}{$\mathrm{SD}$} \\
\hline & Female & Male & & & & \\
\hline Negative & $20(39)$ & $31.6(61)$ & 38 & 12 & - & - \\
\hline Asymptomatic & $6.2(12)$ & $12.4(24)$ & 45 & 9 & - & - \\
\hline Symptomatic & $7.8(15)$ & $21.8(42)$ & 43.33 & 12 & 26 & 19 \\
\hline Total & $34(66)$ & 65.8 (127) & & & & \\
\hline
\end{tabular}

TABLE 3. Performance of tests for three evaluation scenarios

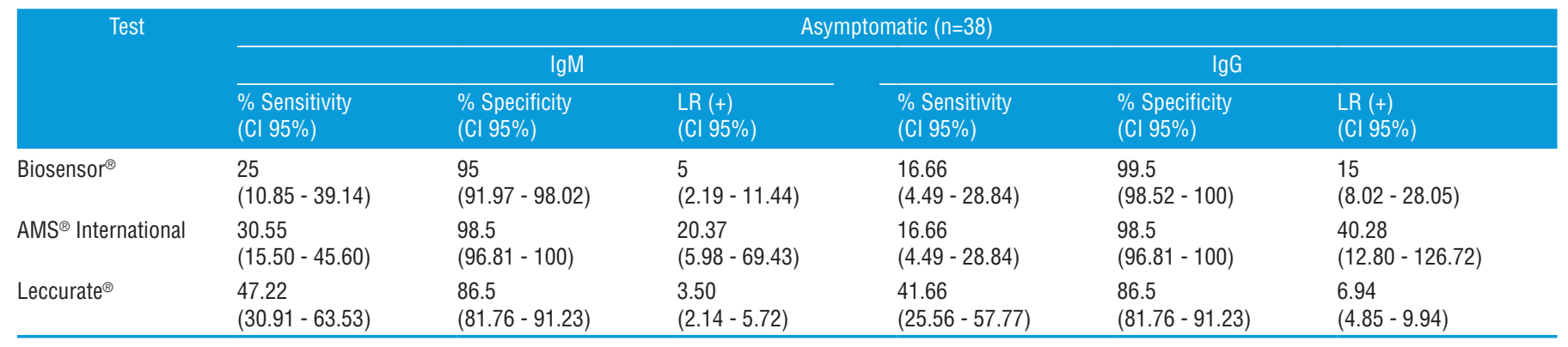


TABLE 3. Performance of tests for three evaluation scenarios (Cont.)

\begin{tabular}{|c|c|c|c|c|c|c|}
\hline \multirow[t]{3}{*}{ Test } & \multicolumn{6}{|c|}{ Asymptomatic ( $\mathrm{n=38})$} \\
\hline & \multicolumn{3}{|c|}{$\lg \mathrm{M}$} & \multicolumn{3}{|c|}{$\lg G$} \\
\hline & $\begin{array}{l}\% \text { Sensitivity } \\
\text { (Cl 95\%) }\end{array}$ & $\begin{array}{l}\text { \% Specificity } \\
\text { (CI 95\%) }\end{array}$ & $\begin{array}{l}\text { LR }(+) \\
(\text { Cl 95\%) }\end{array}$ & $\begin{array}{l}\text { \% Sensitivity } \\
\text { (CI 95\%) }\end{array}$ & $\begin{array}{l}\text { \% Specificity } \\
\text { (CI 95\%) }\end{array}$ & $\begin{array}{l}\text { LR }(+) \\
(\text { Cl 95\%) }\end{array}$ \\
\hline Cromatest COVID-19 ${ }^{\circledR}$ & $\begin{array}{l}39.47 \\
(23.93-55.01)\end{array}$ & $\begin{array}{l}95.50 \\
(92.62-98.37)\end{array}$ & $\begin{array}{l}8.77 \\
(4.14-18.57)\end{array}$ & $\begin{array}{l}15.79 \\
(4.19-27.38)\end{array}$ & $\begin{array}{l}96.50 \\
(93.95-99.04)\end{array}$ & $\begin{array}{l}16.67 \\
(8.62-32.21)\end{array}$ \\
\hline Egens $^{\circledR}$ & $\begin{array}{l}5.26 \\
0-12.36)\end{array}$ & $\begin{array}{l}98 \\
(96.05-99.94)\end{array}$ & $\begin{array}{l}9.21 \\
(4.15-20.43)\end{array}$ & $\begin{array}{l}15.78 \\
(4.19-27.38)\end{array}$ & $\begin{array}{l}96 \\
(93.28-98.71)\end{array}$ & $\begin{array}{l}17.71 \\
(8.77-35.76)\end{array}$ \\
\hline Cellex ${ }^{\circledR}$ & $\begin{array}{l}36.84 \\
(21.50-52.17)\end{array}$ & $\begin{array}{l}96 \\
(93.28-98.71)\end{array}$ & $\begin{array}{l}2.63 \\
(0.50-13.86)\end{array}$ & $\begin{array}{l}18.42 \\
(6.09-30.74)\end{array}$ & $\begin{array}{l}98.5 \\
(96.81-100)\end{array}$ & $\begin{array}{l}18.75 \\
(6.65-52.87)\end{array}$ \\
\hline Onesite Rapidtest ${ }^{\circledR}$ & $\begin{array}{l}26.31 \\
(12.31-40.31)\end{array}$ & $\begin{array}{l}97 \\
(94.63-99.36)\end{array}$ & $\begin{array}{l}8.77 \\
(3.38-22.70)\end{array}$ & $\begin{array}{l}18.42 \\
(6.09-30.74)\end{array}$ & $\begin{array}{l}96.5 \\
(93.95-99.04)\end{array}$ & $\begin{array}{l}5.26 \\
(1.95-14.14)\end{array}$ \\
\hline
\end{tabular}

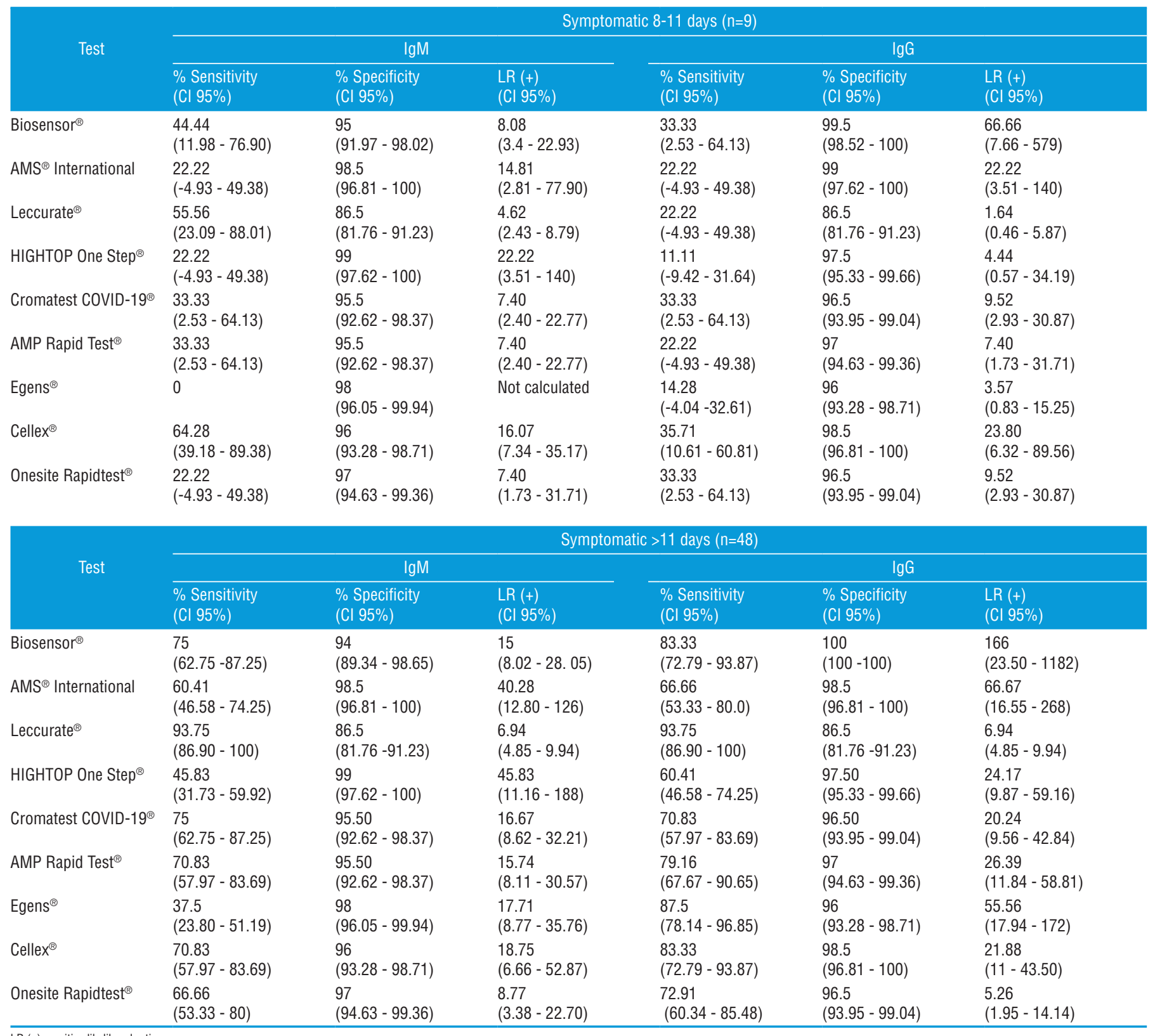




\section{Symptomatic patients between 8-11 days or less from the onset of symptoms}

The sensitivity was low, between $0 \%-64.2 \%$ for $\operatorname{IgM}$ and between $11.11 \%-33.3 \%$ for IgG. The likelihood ratio did not exceed 22 for $\operatorname{IgM}$ and 66.66 for IgG.

\section{Symptomatic patients with more than 11 days since the onset of symptoms}

The sensitivity was low to high, between $37.5 \%-93.75 \%$ for IgM and between $70.83 \%-93.75 \%$ for IgG. Likewise, the positive likelihood ratio did not exceed 45.83 for IgM and 166 for IgG.

\section{Pooled analysis}

A pooled analysis was performed in the asymptomatic and symptomatic groups (less than 11 days and more than 11 days). Asymptomatic patients. The pooled sensitivity of IgM was 0.286 (CI 95\% $0.238-0.337$ ); $\mathrm{p}=0.002 ; \mathrm{I}^{2}=67.9 \%$. The pooled specificity was 0.95 (CI 95\% $0.94-0.96)$, with a high heterogeneity $\left(\mathrm{I}^{2}=81.8 \%\right)$. The pooled PPV was 0.55 (CI 95\% $\left.0.48-0.61\right)$ and NPV was 0.87 (CI 95\% $0.87-0.88$ ). The pooled sensitivity of IgG was 0.19 (CI 95\% $0.15-0.24) \mathrm{p}=0.18 ; \mathrm{I}^{2}=29.6 \%$. The pooled specificity was 0.96 , but showed a high heterogeneity $\left(\mathrm{I}^{2}=84.7 \%\right)$. The pooled PPV and NPV were 0.50 (CI 95\% $0.42-$ $0.57)$ and 0.86 (CI 95\% $0.85-0.86)$ respectively.

When the Leccurate essay was excluded from the analysis there was a reduction in the heterogeneity, and the pooled sensitivity for IgM was 0.26 (CI 95\% $0.21-0.31$ ); $\mathrm{p}=0.010 ; \mathrm{I}^{2}=62.4 \%$.
The pooled specificity was 0.97 (CI 95\% $0.96-0.98$ ); $\mathrm{p}=0.10$; $\mathrm{I}^{2}=40.6 \%$ (Figure 1). Excluding the results from Leccurate, the pooled sensitivity for IgG was 0.17 (CI 95\% $0.12-0.21$ ) p=0.99; $\mathrm{I}^{2}=0 \%$; the pooled specificity was 0.97 (CI 95\% $\left.0.96-0.98\right)$; $\mathrm{p}=0.12 ; \mathrm{I}^{2}=38.6 \%$ (Figure 2 ).

Symptomatic patients between 8-11 days or less from the onset of symptoms. The pooled sensitivity for IgM in this group was 0.33 (CI 95\% $0.23-0.43$ ); $\mathrm{p}=0.007 ; \mathrm{I}^{2}=61.7 \%$. The pooled specificity for IgM was 0.95 (CI 95\% $0.94-0.96$ ) with a high inconsistency $\left(\mathrm{I}^{2}=81.8 \%\right)$. The PPV and NPP were 0.27 (CI 95\% $0.21-0.35)$ and $0.96(\mathrm{CI} 95 \% 0.96-0.97)$ respectively. The pooled sensitivity for IgG was 0.25 (CI 95\% $0.16-0.35) ; \mathrm{p}=0.86 ; \mathrm{I}^{2}=0 \%$. The pooled specificity was 0.96 (CI 95\% $095-0.97)$ with a high inconsistency $\left(\mathrm{I}^{2}=84.7 \%\right)$. The pooled PPV was 0.25 (CI 95\% $0.18-0.34$ ) and the pooled NPV was 0.96 (CI 95\% $0.95-0.96$ ).

When we ran the analysis excluding Leccurate, the pooled sensitivity for IgM was 0.30 (CI 95\% $0.28-0.41$ ); $p=0.009$; $\mathrm{I}^{2}=62.6 \%$ (Figure 1 ). The pooled specificity was 0.97 (CI 95\% $\left.0.95-0.98) ; \mathrm{p}=0.10 ; \mathrm{I}^{2}=40.6 \%\right)$. The pooled specificity for $\mathrm{IgG}$ was 0.25 (CI 95\% $0.16-0.36$ ); $\mathrm{p}=0.79 ; \mathrm{I}^{2}=0 \%$. The grouped specificity was 0.97 (CI 95\% $0.96-0.98$ ); $\mathrm{p}=0.12 ; \mathrm{I}^{2}=38.6 \%$ (Figure 2).

Symptomatic patients with more than 11 days since the onset of symptoms. The pooled analysis for IgM in this group was $0.66(\mathrm{CI} 95 \% 0.61-0.70)$ with a high heterogeneity $\left(\mathrm{I}^{2}=84.3 \%\right)$. The specificity was 0.95 (CI 95\% $0.94-0.96)$, also with a high heterogeneity $\left(\mathrm{I}^{2}=81.8 \%\right)$. The pooled PPV was 0.78 (CI 95\% $0.74-0.82)$; the pooled NPV was 0.92 (CI 95\% $0.91-0.93)$.

The pooled sensitivity for IgG was 0.77 (CI 95\% $0.73-0.81)$; $\mathrm{p}=0.001 ; \mathrm{I}^{2}=69.6 \%$. The specificity was $0.96(\mathrm{CI} 95 \% 0.95-0.97)$

FIGURE 1. Pooled sensitivity and specificity excluding Leccurate of IgM: (A) in asymptomatic group results; (B) in symptomatic group ( $<11$ days).

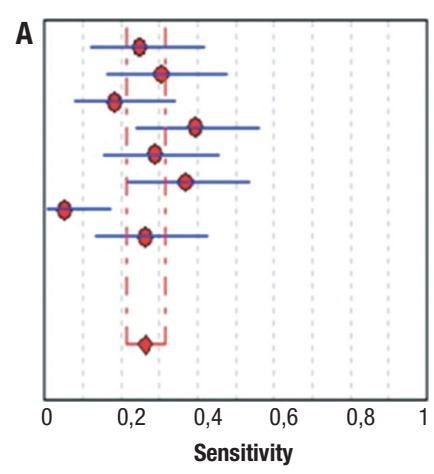

B

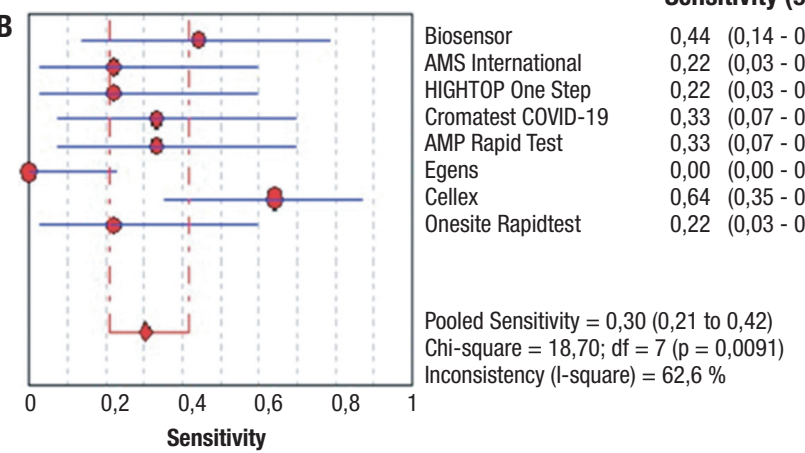

Pooled Sensitivity $=0,26(0,21$ to 0,32$)$

Chi-square $=18,60 ; \mathrm{df}=7(\mathrm{p}=0,0095)$ Inconsistency (l-square) $=62,4 \%$
Sensitivity $(95 \% \mathrm{Cl})$

Biosensor $\quad 0,25(0,12-0,42)$

AMS International $\quad 0,31 \quad(0,16-0,48)$

HIGHTOP One Step $\quad 0,18 \quad(0,08-0,34)$

Cromatest COVID-19 $\quad 0,39(0,24-0,57)$

AMP Rapid Test $\quad 0,29(0,15-0,46)$

Egens $\quad 0,37(0,22-0,54)$

Cellex $\quad 0,05 \quad(0,01-0,18)$

Onesite Rapidtest $\quad 0,26(0,13-0,43)$

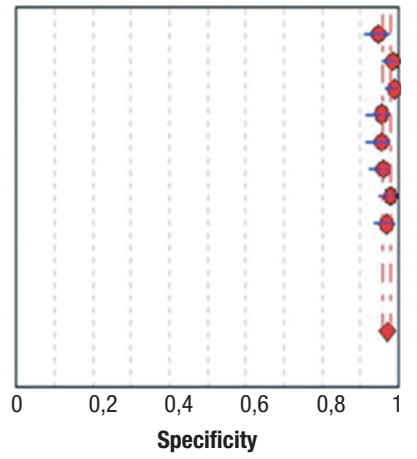

Biosensor

AMS International HIGHTOP One Step

Cromatest COVID-19

AMP Rapid Test

Egens

Cellex

Onesite Rapidtest

Specificity (95\% Cl)

$0,95(0,91-0,98)$

$0,99(0,96-1,00)$

$0,99 \quad(0,96-1,00)$

$0,96(0,92-0,98)$

$0,96(0,92-0,98)$

$0,96(0,92-0,98)$

$0,98 \quad(0,95-0,99)$

$0,97 \quad(0,94-0,99)$

Pooled Specificity $=0,97(0,96$ to 0,98$)$ Chi-square $=11,78 ; d f=7(p=0,1082)$ Inconsistency (I-square) $=40,6 \%$

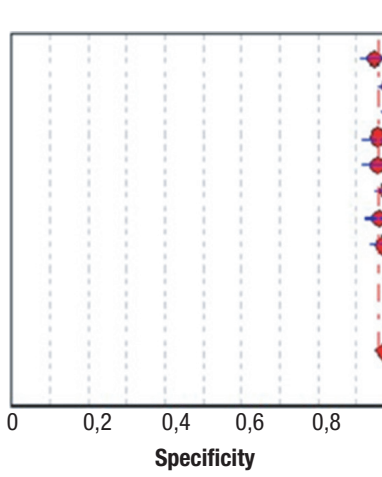

Specificity $(\mathbf{9 5 \%} \mathrm{Cl})$

$0,95 \quad(0,91-0,98)$

$0,99 \quad(0,96-1,00)$

$0,99 \quad(0,96-1,00)$

$0,96 \quad(0,92-0,98)$

$0,96 \quad(0,92-0,98)$

$0,98 \quad(0,95-0,99)$

$0,96 \quad(0,92-0,98)$

$0,97 \quad(0,94-0,99)$

Poled Specificity $=0,97(0,96$ to 0,98$)$

Chi-square $=11,78 ; d f=7(p=0,1082)$

Inconsistency (I-square) $=40,6 \%$ 
FIGURE 2. Pooled sensitivity and specificity excluding Leccurate of IgG: (A) in asymptomatic group; (B) in symptomatic group (<11 days); and (C) in symptomatic group ( $>11$ days).

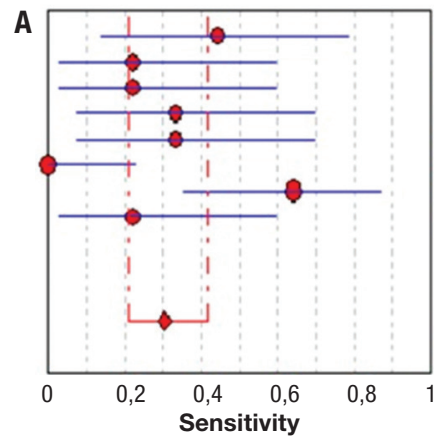

B
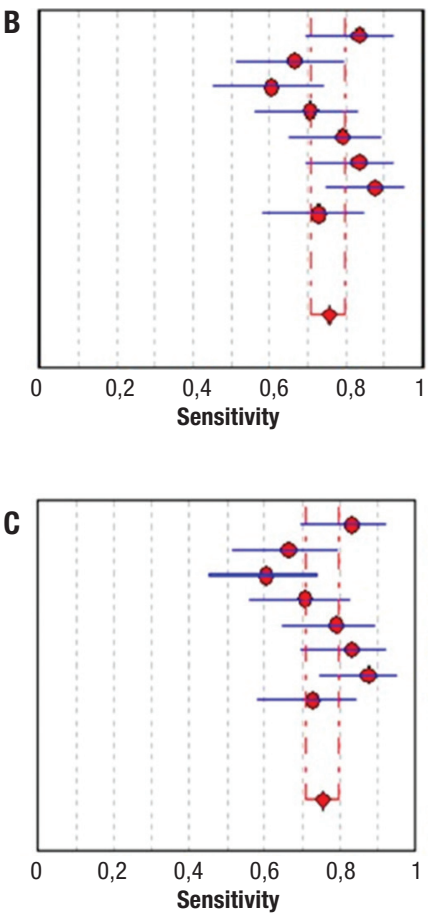

Biosensor AMS International HIGHTOP One Step AMP Rapid Test

Egens

Cellex

Onesite Rapidtest

Pooled Sensitivity $=0,76(0,71$ to 0,80$)$

Chi-square $=16,05 ; d f=7(p=0,0247)$

Inconsistency (I-square) $=56,4 \%$

Pooled Sensitivity $=0,30(0,21$ to 0,42$)$

Chi-square $=18,72 ; \mathrm{df}=7(\mathrm{p}=0,0091)$

Biosensor

HIGHTOP One Step

Cromatest COVID-19

Pooled Sensitivity $=0,76(0,71$ to 0,80$)$

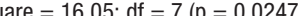
Cromatest COVID-19

\section{Sensitivity $\mathbf{( 9 5 \%} \mathbf{~ C l )}$}

$0,44(0,14-0,79)$

$0,22(0,03-0,60)$

$0,22(0,03-0,60)$

$0,33(0,07-0,70)$

$0,33(0,07-0,70)$

$0,00(0,00-0,23)$

$0,64(0,35-0,87)$

$0,22(0,03-0,60)$

Sensitivity (95\% Cl)

$0,83(0,70-0,93)$

$0,60(0,45-0,74)$

, $71(0,56-0,83)$

$(0,70-0,93)$

$0,88(0,75-0,95)$

$0,73(0,58-0,85)$

\section{Sensitivity (95\% Cl)}

$(0,52-0,80)$

$0,60(0,45-0,74)$

$0,71(0,56-0,83)$

$0,79(0,65-0,90)$

$0,83(0,70-0,93)$

$0,88(0,75-0,95)$

$0,73(0,58-0,85)$

with high inconsistency $\left(\mathrm{I}^{2}=84.7 \%\right)$. The pooled PPV and NPV were 0.83 (CI 95\% $0.79-0.86$ ) and 0.94 (CI 95\% $0.93-0.95)$.

The pooled sensitivity for IgM excluding the Leccurate test was 0.62 (CI 95\% $0.57-0.67)$; however, the inconsistency remained high $\left(\mathrm{I}^{2}=74.9 \%\right)$. The pooled specificity was 0.96 (CI 95\% $0.95-0.97) ; \mathrm{p}=0.10 ; \mathrm{I}^{2}=40.6 \%$. In the case of $\mathrm{IgG}$, the pooled sensitivity was 0.75 (CI 95\% $0.70-0.79$ ); $\mathrm{p}=0.02$; $\mathrm{I}^{2}=56.4 \%$. The pooled specificity was 0.97 (CI 95\% $0.96-0.98$ ); $\mathrm{p}=0.12 ; \mathrm{I}^{2}=38.6 \%$ (Figure 2 ).

\section{DISCUSSION}

In this study, we evaluated nine commercial immunochromatographic tests for the detection of anti-SARS-CoV-2 IgM and IgG antibodies. Our results showed that the best sensitivity performance of the tests occurred for IgG in the group of symptomatic patients with more than 11 days after the onset of symptoms. On the contrary, the worst performance occurred

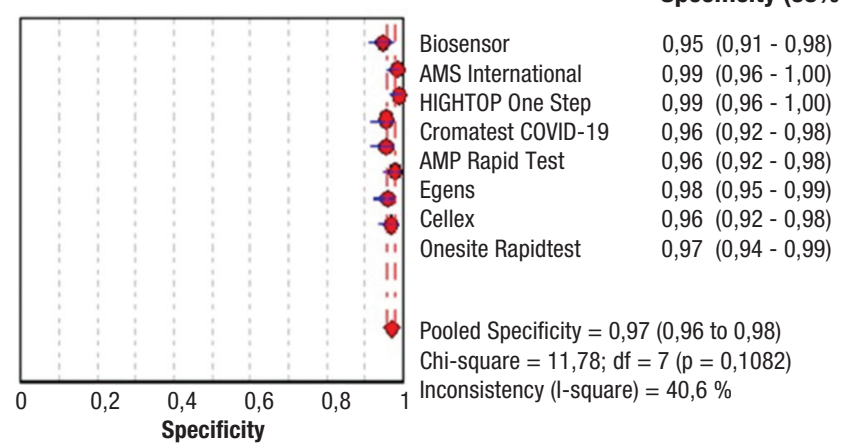

Specificity (95\% CI)

$(0,96-1,00)$

$0,96(0,92-0,98)$

, $98(0,95-0,99)$

$0,96(0,92-0,98)$

Specificity (95\% CI)

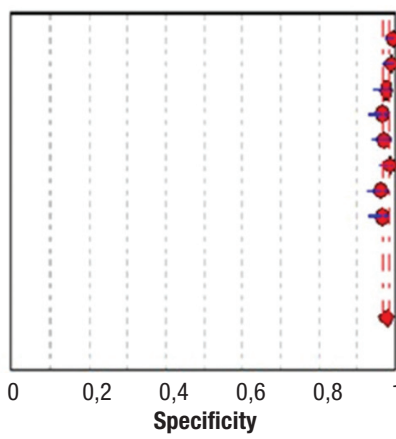

Biosensor

AMS International

HIGHTOP One Step

Cromatest COVID-19

AMP Rapid Test

Egens

Cellex

Onesite Rapidtest

$1,00(0,97-1,00)$

$0,99(0,96-1,00)$

$0,98(0,94-0,99)$

$0,97(0,93-0,99)$

$0,97(0,94-0,99)$

$0,99(0,96-1,00)$

$0,96(0,92-0,98)$

$0,97(0,93-0,99)$

Pooled Specificity $=0,98(0,97$ to 0,98$)$

Chi-square $=11,39 ; \mathrm{df}=7(\mathrm{p}=0,1223)$

Inconsistency (l-square) $=38,6 \%$

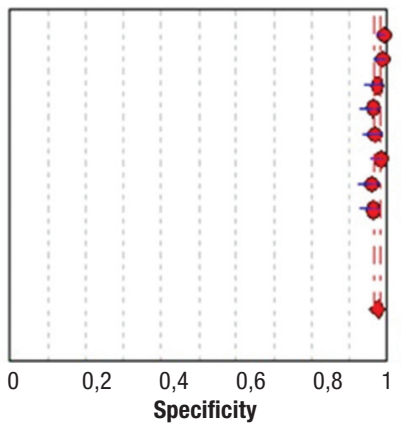

Specificity $(95 \% \mathrm{Cl})$

$1,00(0,97-1,00)$

$0,99(0,96-1,00)$

$0,98(0,94-0,99)$

$0,97(0,93-0,99)$

$0,97(0,94-0,99)$

$0,99(0,96-1,00)$

$0,96(0,92-0,98)$

$0,97(0,93-0,99)$

Pooled Specificity $=0,98(0,97$ to 0,98$)$

Chi-square $=11,39 ; d f=7(p=0,1223)$

Inconsistency (l-square) $=38,6 \%$ in the asymptomatic group ( $\operatorname{Ig} M$ and $\operatorname{IgG})$, were the sensitivity was less than $40 \%$.

These findings are similar to those reported in the literature. The study from Vidal-Anzardo et al (10) comparing serological rapid tests against molecular tests in a population of 143 patients from Peru reported that the sensitivity of the serological rapid test is high from the second week of symptoms. On the other hand, it has also been reported better performance of the test in patients who presented clinical symptoms longer than 12 days $(17,18)$. Zhang et al reported that the utility of these serological tests is increased in patients with at least 8 days of clinical evolution (19). The author identified that the use of serological tests for the detection of specific anti-SARS-CoV-2 antibodies in febrile patients is useful to carry out differential diagnosis, but that it should be used in addition to molecular tests. Hoffman et al evaluated an essay for COVID-19 IgG/IgM serological rapid test cassette (17). The study included 29 PCR-confirmed COVID-19 cases from a Swedish hospital and 124 negative 
controls from a biobank. The authors reported a sensitivity of $69 \%$ and $93.1 \%$ for $\operatorname{IgM}$ and $\operatorname{IgG}$, and suggested that the test is not suitable for massive screening. Cassaniti et al reported the results of a diagnostic essay carried out to evaluate the performance of VivaDiag COVID-19 IgM/IgG serological rapid test in an emergency service in Italy (20). The study involved 110 subjects (30 positive for COVID-19). The authors reported a sensitivity of $18.4 \%$ and a specificity of $91.7 \%$. A German study aimed to evaluate the diagnostic capability of a rapid point-ofcare test for SARS-CoV-2 in a community screening (21). The study included 49 individuals (11 positive for SARS-CoV-2 confirmed by RT-PCR). The authors reported a sensitivity of $36.4 \%$ and a specificity of $88.9 \%$ ). Ong et al compared the diagnostic accuracy of serological rapid tests in patients with suspected coronavirus disease 2019 (22). The study evaluated five commercial rapid tests (Boson Biotech Rapid 2019-nCoV IgG/IgM Combo Test Card; Cellex qSARS-CoV-2 IgG/IgM Cassette Rapid Test; Dynamiker Biotechnology 2019-nCOV IgG/IgM Rapid Test; Orient Gene Biotech COVID-19 IgG/IgM Rapid Test Cassette; and Prometheus Bio 2019-nCOV IgG/IgM Rapid) (22). It involved 228 samples from positive inpatients admitted in a hospital in the Netherlands. Authors reported heterogeneous sensitivities ranging from $10 \%(95 \%$ CI $0 \%-23 \%)$ to $55 \%(95 \%$ CI 33\%-77\%). The test with the best performance was the Orient Gene Biotech COVID-19 IgG/IgM Rapid Test (OGBRT) (22).

Consistent with the reported literature, our findings showed a lower performance for sensitivity in all the study groups. These results differ from the reported sensitivity and specificity values from commercial manufactures, which may occur for many different reasons. First, most of the experiments in the clinical reports from the manufactures did not report the origin (country) used to evaluate the operative capability of the assays. The results may change from one country to other, or may be affected by conditions such as ethnicity and the time of the onset of symptoms. Second, some of the information leaflets reported several samples used to estimate the sensitivity and specificity, but all of them fail to report the clinical stage of the patients. Besides, none of the tests reported the inclusion of serum from asymptomatic patients. This may result in an overestimation of the sensitivity of the test. Third, it should be considered that most of the clinical reports from commercial manufacturers are not published in peer-reviewed journals, were independent readers may evaluate the experiment conditions. Lastly, it should be taken into account the diversity of the SARS-CoV-2 strains circulating in Colombia. Recent reports from the phylogenetic analysis of SARS-CoV-2 in Colombia have shown that the lineages B.1.1, B.1.5 of SARS-CoV-2 are the most common in the country $(23,24)$. These lineages have been reported in studies from Europe, the United States and Australia (25). The described lineages may be linked with low performance of rapid diagnostic tests, as reported in Italian, German, and Dutch studies (20-22).

We should mention the case of the Leccurate test, which performance highly differs from the other 8 tests. Even when we carried out a subgroup analysis considering the manufacturing place (Asia vs Europe; Asia vs United States; China vs Europe; China vs United States) the results of the pooled analysis increased the inconsistency. We did not find a reason to explain the heterogeneity shown by the above mentioned test.

Also, we have found that the best performance of the test occurred in the group of patients with 11 or more days of evolution. We calculated a pooled sensitivity of 76\% (CI $71-80)$ and a pooled specificity of $98 \%$ (CI $97-98$ ) for IgG. These results differ slightly from the reported by Castro et al in a metanalysis to estimate the pooled sensitivity and specificity in a group of 16 COVID-19 serological rapid tests available in Brazil (26). The authors reported a sensitivity of $82 \%$ (CI $76-87$ ) and a specificity of $97 \%$ (CI $96-98$ ) for IgM, and a sensitivity of $97 \%$ (CI 90 - 99) and specificity of 98\% (CI 97 - 99) for IgG. Nevertheless, the authors highlighted the high rate of false negative results of these tests in the acute phase of the infection, which may range between $10-44 \%$. Also, they urged for a validation study using Brazilian samples (26).

In this sense, our study using samples from Colombian serums found that serological rapid tests should be limited to patients with more than 11 days of symptoms. Besides, the serological tests are not an adequate strategy for the identification of asymptomatic and pre-symptomatic patients. The recommendations from the World Health Organization should be taken into account; they should be avoided as a diagnostic test and they must be accompanied by RT-PCR (8).

This study has some limitations. First, in the absence of a gold standard test, RT-PCR was used. Nucleic acid detection by the Berlin protocol, although standardized and validated by the US National Institutes of Health, may have some false negatives, especially during the first days of the clinical picture. On the other hand, the pooled sensitivity analyses for IgM and IgG in the asymptomatic and symptomatic groups showed moderate heterogeneities, which could invalidate the pooled sensitivity data.

All in all, serological tests are essential to analyze the immune response against infectious diseases to carry out their epidemiological characterization, natural resistance or susceptibility, and the study of potential vaccines. In cases such as the SARSCoV-2 pandemic, the secondary validation of the available tests is essential to establish their usefulness as well as their limitations. Our study showed that the usefulness of immunochromatographic serological tests for COVID-19 is limited and its use as a diagnostic tool has led to a large proportion of false negatives promoting the contagion. Immunochromatographic tests may be used in seroprevalence studies once more sensible antigens are incorporated in the technique, making them suitable tests for screening the infectious population.

Funding. This study was supported by the Instituto Nacional de Salud within the framework of the resources provided for the COVID-19 pandemic.

\section{Conflict of interests. None declared.}

Authors' contributions. All authors have participated in the design, analysis of results, writing and revision of the document, and final approval of the manuscript.

Acknowledgements. The authors thank Professor Owen Harrison for the revision of the manuscript; to Dr. Sofía Duque who kindly reviewed the last version of the manuscript and provided valuable suggestions and comments.

Disclaimer. Authors hold sole responsibility for the views expressed in the manuscript, which may not necessarily reflect the opinion or policy of the RPSP/PAJPH and/or PAHO. 


\section{REFERENCES}

1. Zhou P, Yang X-L, Wang X-G, Hu B, Zhang L, Zhang W, et al. A pneumonia outbreak associated with a new coronavirus of probable bat origin. Nature. 2020 Mar;579(7798):270-3.

2. Udugama B, Kadhiresan P, Kozlowski HN, Malekjahani A, Osborne M, Li VYC, et al. Diagnosing COVID-19: The Disease and Tools for Detection. ACS Nano [Internet]. 2020 Mar 30 [cited 2020 Apr 17]. Available from: https://www.ncbi.nlm.nih.gov/pmc/articles/PMC7144809/

3. Musselwhite C, Avineri E, Susilo Y. Editorial JTH 16 -The Coronavirus Disease COVID-19 and implications for transport and health. J Transp Health [Internet]. 2020 Mar [cited 2020 May 6];16:100853. Available from: https://www.ncbi.nlm.nih.gov/pmc/articles/PM C7174824/

4. di Giacomo E, Bellelli G, Peschi G, Scarpetta S, Colmegna F, Girolamo G, et al. Management of older people during the COVID-19 outbreak: Recommendations from an Italian experience. Int J Geriatr Psychiatry [Internet]. 2020 Jul [cited 2020 Sep 24];35(7):803-5. Available from: https:/ / onlinelibrary.wiley.com/doi/abs/10.1002/ gps.5318

5. Bachelet VC. Do we know the diagnostic properties of the tests used in COVID-19? A rapid review of recently published literature. Medwave [Internet]. 2020 Apr 28 [cited 2020 May 6];20(3). Available from: /link.cgi/English/Reviews/GeneralReviews/7891.act

6. Long Q-X, Liu B-Z, Deng H-J, Wu G-C, Deng K, Chen Y-K, et al. Antibody responses to SARS-CoV-2 in patients with COVID-19. Nat Med [Internet]. 2020 Apr 29 [cited 2020 May 6];1-4. Available from: https:/ / www.nature.com/articles/s41591-020-0897-1

7. Xiang F, Wang X, He X, Peng Z, Yang B, Zhang J, et al. Antibody Detection and Dynamic Characteristics in Patients with COVID-19. Clin Infect Dis [Internet]. 2020 Apr 19 [cited 2020 May 6]:ciaa461. Available from: https://www.ncbi.nlm.nih.gov/pmc/articles/ PMC7188146/

8. World Health Organization. Advice on the use of point-of-care immunodiagnostic tests for COVID-19: scientific brief, 8 April 2020 [Internet]. Geneva: World Health Organization; 2020. Available from: https:/ /apps.who.int/iris/handle/10665/331713

9. Hajian-Tilaki K. Sample size estimation in diagnostic test studies of biomedical informatics. J Biomed Inform [Internet]. 2014 Apr 1 [cited 2020 May 7];48:193-204. Available from: http://www.sciencedirect.com/science/article/pii/S1532046414000501

10. Vidal-Anzardo M, Solis G, Solari L, Minaya G, Ayala-Quintanilla B, Astete-Cornejo J, et al. Evaluación en condiciones de campo de una prueba serológica rápida para detección de anticuerpos IgM e IgG contra SARS-CoV-2. Rev Peru Med Exp Salud Pública [Internet]. 2020 Apr 21 [cited 2020 May 12];37(2). Available from: https:// rpmesp.ins.gob.pe/index.php/rpmesp/article/view/5534

11. Corman VM, Landt O, Kaiser M, Molenkamp R, Meijer A, Chu DK, et al. Detection of 2019 novel coronavirus (2019-nCoV) by real-time RT-PCR. Eurosurveillance [Internet]. 2020 Jan 23 [cited 2020 Jun 27];25(3). Available from: https://www.ncbi.nlm.nih.gov/pmc/ articles/PMC6988269/

12. Silva Fuente-Alba C, Molina Villagra M. Likelihood ratio (razón de verosimilitud): definición y aplicación en Radiología. Rev Argent Radiol [Internet]. 2017 Jul 1 [cited 2020 May 7];81(3):204-8. Available from: http://www.elsevier.es/es-revista-revista-argentina-rad iologia-383-articulo-likelihood-ratio-razon-verosimilitud-definicio n-S0048761916301910

13. Aznar-Oroval E, Mancheño-Alvaro A, García-Lozano T, Sánchez-Yepes M. Razón de verosimilitud y nomograma de Fagan: 2 instrumentos básicos para un uso racional de las pruebas del laboratorio clínico. Rev Calid Asist [Internet]. 2013 Nov 1 [cited 2020 May 7];28(6):390-1. Available from: http://www.elsevier.es/es-revista-revista-calidad-asistencial-256-articulo-razon-verosimilitud-n omograma-fagan-2-S1134282X13000523

14. Higgins JPT, Thompson SG, Deeks JJ, Altman DG. Measuring inconsistency in meta-analyses. BMJ [Internet]. 2003 Sep 4 [cited 2020 Jun 16];327(7414):557-60. Available from: https://www.bmj.com/ content $/ 327 / 7414 / 557$

15. Thorlund K, Imberger G, Johnston BC, Walsh M, Awad T, Thabane L, et al. Evolution of Heterogeneity $\left(\mathrm{I}^{2}\right)$ Estimates and Their $95 \%$
Confidence Intervals in Large Meta-Analyses. Emmert-Streib F, editor. PLoS ONE [Internet]. 2012 Jul 25 [cited 2020 Jun 27];7(7):e39471. Available from: https:/ /dx.plos.org/10.1371/journal.pone.0039471

16. Zamora J, Abraira V, Muriel A, Khan K, Coomarasamy A. MetaDiSc: a software for meta-analysis of test accuracy data. BMC Med Res Methodol [Internet]. 2006 Dec [cited 2020 Jun 16];6(1):31. Available from: https://bmcmedresmethodol.biomedcentral.com/ articles /10.1186/1471-2288-6-31

17. Hoffman T, Nissen K, Krambrich J, Rönnberg B, Akaberi D, Esmaeilzadeh M, et al. Evaluation of a COVID-19 IgM and IgG rapid test; an efficient tool for assessment of past exposure to SARS-CoV-2. Infect Ecol Epidemiol [Internet]. 2020 Apr 14 [cited 2020 May 12];10(1). Available from: https://www.ncbi.nlm.nih.gov/pmc/articles/ PMC7178815/

18. Delgado G, Vargas J, Mercado M, Gaviria P, Álvarez C. Toward to establish selection criteria for rapid serological tests for COVID-19. Infectio [Internet]. 2020 May 12 [cited 2020 Sep 24];24(3):17. Available from: http:/ /www.revistainfectio.org/index.php/infectio/arti cle/view/869

19. Zhang J, Liu J, Li N, Liu Y, Ye R, Qin X, et al. Serological detection of 2019-nCoV respond to the epidemic: A useful complement to nucleic acid testing. medRxiv. 2020 Mar 10;2020.03.04.20030916.

20. Cassaniti I, Novazzi F, Giardina F, Salinaro F, Sachs M, Perlini S, et al. Performance of VivaDiag COVID-19 IgM/IgG Rapid Test is inadequate for diagnosis of COVID-19 in acute patients referring to emergency room department. J Med Virol [Internet]. 2020 Apr 8 [cited 2020 Sep 17];jmv.25800. Available from: https: / / onlinelibrary. wiley.com/doi/abs/10.1002/jmv.25800

21. Döhla M, Boesecke C, Schulte B, Diegmann C, Sib E, Richter E, et al. Rapid point-of-care testing for SARS-CoV-2 in a community screening setting shows low sensitivity. Public Health [Internet]. 2020 May [cited 2020 Sep 17];182:170-2. Available from: https://linkinghub. elsevier.com/retrieve/pii/S0033350620301141

22. Ong DSY, de Man SJ, Lindeboom FA, Koeleman JGM. Comparison of diagnostic accuracies of rapid serological tests and ELISA to molecular diagnostics in patients with suspected coronavirus disease 2019 presenting to the hospital. Clin Microbiol Infect [Internet]. 2020 Aug [cited 2020 Sep 17];26(8):1094.e7-1094.e10. Available from: https://linkinghub.elsevier.com/retrieve/pii/S1198743X203 03050

23. Malagón-Rojas J, Mercado M, Ospina M, Parra E. Portadores asintomáticos de SARS-CoV-2: cohorte de viajeros y trabajadores del aeropuerto internacional El Dorado de Bogotá, 2020 [Internet]. XII Encuentro Nacional de Enfermedades infecciosas; 2020 Sep 25; Cali, Colombia. Available from: https:/ / www.acin.org/index.php/ acin/eventos

24. Laiton-Donato K, Villabona Arenas CJ, Usme Ciro JA, Franco Munoz C, Alvarez-Diaz DA, Villabona-Arenas LS, et al. Genomic epidemiology of SARS-CoV-2 in Colombia [Internet]. Infectious Diseases (except HIV/AIDS); 2020 Jun [cited 2020 Sep 24]. Available from: http://medrxiv.org/lookup/doi/10.1101/2020.06.26.20135715

25. Rambaut A, Holmes EC, O'Toole Á, Hill V, McCrone JT, Ruis C, et al. A dynamic nomenclature proposal for SARS-CoV-2 lineages to assist genomic epidemiology. Nat Microbiol [Internet]. $2020 \mathrm{Jul}$ 15 [cited 2020 Sep 24]. Available from: http://www.nature.com/ articles/s41564-020-0770-5

26. Castro R, Luz PM, Wakimoto MD, Veloso VG, Grinsztejn B, Perazzo H. COVID-19: a meta-analysis of diagnostic test accuracy of commercial assays registered in Brazil. Braz J Infect Dis [Internet]. 2020 Mar [cited 2020 Jun 27];24(2):180-7. Available from: https:/ / linkinghub.elsevier.com/retrieve/pii/S1413867020300295

Manuscript received on 23 July 2020. Revised version accepted for publication on 2 October 2020 


\section{Evaluación de nueve pruebas serológicas rápidas para la detección del SARS-CoV-2}

RESUMEN Objetivo. Evaluar la capacidad operativa de nueve pruebas serológicas rápidas para detectar la respuesta de anticuerpos IgM/lgG en el suero de pacientes con SARS-CoV-2 en diferentes etapas clínicas.

Métodos. Se diseñó un estudio transversal de las pruebas serológicas rápidas para comparar su rendimiento respecto del diagnóstico del SARS-CoV-2. Se utilizaron en total 293 muestras, inclusive muestras de suero de pacientes negativos, asintomáticos y sintomáticos.

Resultados. La sensibilidad de las pruebas evaluadas fue baja y moderada en las muestras de suero del grupo de pacientes asintomáticos y en el grupo de pacientes con menos de 11 días desde el inicio de los síntomas. La especificidad de las pruebas de anticuerpos anti-SARS-CoV-2 varió entre 86,5\%-99\% para la IgM y $86,5 \%-99,5 \%$ para la IgG. La sensibilidad y la razón de verosimilitud (likelihood ratio) fueron diferentes según los grupos de estudio. La utilidad de estas pruebas se limita a los pacientes sintomáticos y su sensibilidad es superior al 85\% después de 11 días de la aparición de los síntomas.

Conclusiones. Las pruebas serológicas no son una estrategia adecuada para la identificación de los pacientes asintomáticos y presintomáticos. Las pruebas serológicas rápidas para la detección de anticuerpos específicos anti-SARS-CoV-2 pueden ser utilizadas como ayuda diagnóstica, pero el diagnóstico debe ser confirmado por RT-PCR. Las pruebas rápidas deben reservarse para los pacientes con síntomas que duren más de 11 días.

Palabras clave Betacoronavirus; infecciones por coronavirus; pruebas serológicas; diagnóstico; Colombia. 